\title{
Wkład polskich historyków prawa w badania nad prawem magdeburskim w XX w. (1945-2010)
}

Jeśli będziesz czytał, a nie wszytkoć pójdzie w smak, łaskawy Czytelniku, nie zarazem łaj, ale pierwej pilnie czytając rozeznaj...

Bartłomiej Groicki, Porzqdek sadów i spraw miejskich prawa majdeburskiego w Koronie Polskiej

\section{Uwagi wstępne}

Historiografia polska XX wieku w znaczącym stopniu przyczyniła się do poznania, opracowania i upowszechnienia wyników badań nad prawem magdeburskim - najważniejszym systemem prawa miejskiego dawnej Polski. Magdeburg nad Łabą, wzmiankowany już na początku IX w., zyskał na znaczeniu za pierwszego cesarza niemieckiego Ottona I (936-973). Urządzenie w mieście siedziby arcybiskupa (968) przyczyniło się do rozwoju życia jego mieszkańców, którzy szybko zdobyli znaczne przywileje i swobody. Wzorzec miejski Magdeburga przyjęły liczne miasta niemieckie ${ }^{1}$. W 1188 r., po pożarze miasta, jego władca arcybiskup Wichmann nadał Mag-

\footnotetext{
1 Najpierw Stendal (1160), a następnie Halle nad Soławą, Lipsk i wiele dalszych miejscowości.
} 
deburgowi przywilej, który szybko zyskał modelowy charakter ${ }^{2}$. Już w 1211 r. został on użyczony Złotoryi na Śląsku, a w 1233 r. Chełmnu i Toruniowi. Wraz z lokacją Złotoryi (Goldberg) rozpoczął się, najpierw na Śląsku, a następnie w Małopolsce, Wielkopolsce, na Pomorzu Gdańskim i Mazowszu, proces tworzenia gmin miejskich prawa niemieckiego, opartych na wzorcu magdeburskim. Początkowo prawo magdeburskie było, jak wiadomo, tylko prawem napływowej ludności - kolonistów przybywających $z$ Niemiec na ziemie polskie. $Z$ czasem stało się podstawą organizacyjno-prawną przy zakładaniu licznych miast i wsi. Dokumenty lokacyjne wskazywały w takich wypadkach ius magdeburgense albo też ius teutonicum vel (alias) magdeburgense. Niektóre miasta lokowane na prawie magdeburskim dały podstawę do ukształtowania się jego odmian - tak narodziły się w szczególności prawo chełmińskie (ius culmense) oraz prawo średzkie (ius novi fori) ${ }^{3}$.

Badania nad prawem magdeburskim prowadzili i nadal prowadzą przedstawiciele różnych dziedzin polskiej nauki: historycy, archeolodzy, filolodzy, urbaniści, historycy sztuki i inni specjaliści, w tym historycy prawa. W ostatnich latach najbardziej spektakularnym rezultatem badań historycznych, uwzględniających zdobycze wielu wyspecjalizowanych dziedzin, była zorganizowana w 2007 r. przez Muzeum Historyczne Miasta Krakowa wystawa, a zwłaszcza towarzyszące jej monumentalne wydawnictwo zatytułowane Kraków: europejskie miasto prawa magdeburskiego (1257-1791)4. Przedmio-

2 Podstawą prawa magdeburskiego było - jak wiadomo - zwyczajowe prawo wschodniej Saksonii, zawarte w Zwierciadle saskim (Speculum Saxonum; Sachsenspiegel) - zwodzie prawa sporządzonym (najpierw po łacinie, a potem w języku niemieckim) przez ławnika sądowego Eike von Repgowa w latach 1221-1224, oraz Weichbild magdeburski (Ius municipale), powstały z połączenia traktatu o prawie miejskim sprzed 1269 r. oraz z prawa ławników magdeburskich (Magdeburger Schöffenrecht) z 2. połowy XIII w.

3 Por. opinię historyków co do tego, że prawo Magdeburga było „przetwarzane nie tylko w każdej dzielnicy, ale nawet w każdej większej włości feudalnej, zgodnie z potrzebami właściciela” - H. Samsonowicz, A. Wyczański, J. Tazbir, J. Staszewski, T. Kizwalter, T. Nałęcz, A. Paczkowski, A. Chwalba, Historia Polski, t. 1, Warszawa 2007, s. 84.

4 Podtytuł: Katalog wystawy, Kraków 2007. 
tem niniejszego opracowania są jednak wyłącznie osiągnięcia badawcze polskich historyków prawa, zajmujących się szeroko pojętym prawem magdeburskim ${ }^{5}$.

Historycy prawa, podobnie jak inni badacze, już w XIX w. przystąpili do edycji źródeł prawa magdeburskiego oraz do opracowania ustroju miast, a także wybranych instytucji prawa miejskiego ${ }^{6}$. Jednym $z$ pierwszych zasłużonych historyków prawa i wydawców źródeł był Jan Wincenty Bandtkie (1783-1846) ${ }^{7}$, profesor Uniwersytetu Warszawskiego. W Galicji działalność edytorską względnie badawczą podjęli profesorowie Uniwersytetu Jagiellońskiego: Michał Bobrzyński (1849-1935) ${ }^{8}$ - prawnik i historyk, Franciszek Pieko-

${ }^{5}$ W literaturze przedmiotu znajdujemy wprawdzie ogólne prezentacje stanu badań polskiej historiografii prawnej nad prawem magdeburskim, lecz pojawiają się one zwykle tylko na marginesie monografii lub rozpraw poświęconych dziejom czy instytucjom dawnego prawa miejskiego. W historiografii ogólnej opis wkładu historyków prawa w badania nad powstaniem miast i wsi oraz nad dawnym prawem miejskim i wiejskim zajmuje margines; dla przykładu: w interesującej, obszernej i nowoczesnej monografii J.M. Piskorskiego, Deutsche Ostforschung und polnische Westforschung im Spannungsfeld von Wissenschaft und Politik. Disziplinen im Vergleich, Osnabrück-Poznań 2002 pojawiają się zaledwie skąpe uwagi o poglądach naukowych $Z$. Kaczmarczyka i Z. Wojciechowskiego; o innych historykach prawa nie ma już (z różnych powodów) ani słowa.

6 Por. syntetyczny opis osiągnięć polskich historyków prawa XIX w. A. Bereza, G. Smyk, W.P. Tekely, Legal Science on the Polish Territories in the 19th Century, [w:] Rechtswissenschaft in Osteuropa. Studien zum 19. und frühen 20. Jahrhundert, wyd. Zoran Pokrovac, Frankfurt am Main 2010, s. 60-62.

7 A. Rosner, Jan Wincenty Bandtkie (1783-1846), [w:] Profesorowie Wydziału Prawa i Administracji Uniwersytetu Warszawskiego 1808-2008, red. G. Bałtruszajtys, Warszawa 2008, s. 23-25. Por. Polski słownik biograficzny (dalej: PSB) 1, s. 259-260. Bandtkie opublikował m.in. Jus culmense cum appendice privilegiorum et jurium selectorum municipalium et dissertatione historicojuridica, Warszawa 1814; Zbiór rozpraw o przedmiotach prawa polskiego, Warszawa-Wilno 1812 (Rozdział VI. O prawach chetmińskim i lubeckim $w$ szczególności, s. 156-172).

8 Por. PSB 2, s. 165-168. Bobrzyński zapisał się jako edytor źródeł: Ortyle magdeburskie (Poznań 1876), a ponadto jako autor Historii prawa 
siński (1844-1906) ${ }^{9}$ - prawnik i wybitny mediewista, oraz przedwcześnie zmarły Lotar Dargun (1853-1893) ${ }^{10}$. Na przełomie XIX i XX w. w Uniwersytecie Jagiellońskim rozpoczął działalność naukową Stanisław Kutrzeba (1876-1946) ${ }^{11}$ - znany i wybitny prawnik oraz historyk, a przy tym dobry znawca dziejów prawa miejskiego ${ }^{12}$.

Warto przypomnieć w tym miejscu, że wymienieni uczeni generalnie reprezentowali stanowisko, że niemieckie osadnictwo miało decydujący i przełomowy wpływ na rozwój miast na ziemiach polskich. Pogląd ten poddał weryfikacji prawnik i historyk Oswald Balzer (1858-1933) ${ }^{13}$, profesor Uniwersytetu Lwowskiego. Badacz ten wysunął tezę o istnieniu na ziemiach polskich licznych zalążków miast w okresie przed kolonizacją niemiecką oraz zaproponował rozdzielenie dwóch pojęć: „kolonizacja niemiecka” i „kolonizacja na prawie niemieckim"14. Debata na temat ewolucyjnego rozwoju miast

niemieckiego $w$ zarysie (Kraków 1876) oraz rozprawy na temat sądu wyższego prawa niemieckiego na zamku krakowskim, opublikowanej w Rozprawach i Sprawozdaniach PAU, t. 4: 1875, s. 1-170.

${ }^{9}$ Por. PSB 26, s. 77-81. Piekosiński napisał m.in. rozprawę $O$ sądach wyższych prawa niemieckiego w Polsce wieków średnich, Rozprawy i Sprawozdania PAU, Bd.18, Kraków 1885, s. 1-62.

${ }_{10}$ Por. PSB 4, s. 436-437. Dargun wydał cenne rozprawy: O źródłach prawa miast polskich $w$ wieku szesnastym, cz. 1: O źródłach przepisów karnych $w$ dziełach Groickiego, cz. 2: O źródłach porządku sądowego spraw miejskich prawa magdeburskiego przez B. Groickiego, Kraków 1888-1890. Obok wymienionych historyków prawa twórczość rozpoczynali też historycy Jan Ptaśnik i Stanisław Smolka.

${ }^{11}$ Por. PSB 16, s. 314-318. Zob. też Stanisław Kutrzeba 1876-1946. Materiały z Uroczystego Posiedzenia Polskiej Akademii Umiejętności, Kraków 1998; W. Uruszczak, Stanisław Kutrzeba (1876-1946), [w:] Uniwersytet Jagielloński. Złota Księga Wydziału Prawa i Administracji, red. J. Stelmach, W. Uruszczak, Kraków 2000, s. 291-296.

${ }^{12}$ S. Kutrzeba w opublikowanej Historii źródeł dawnego prawa polskiego (Lwów-Warszawa-Kraków 1925-1926) dał syntetyczny obraz dziejów prawa miejskiego od lokacji do XVIII w. (t. 2, s. 198-284). Warto dodać, że Kutrzeba był uczniem B. Ulanowskiego (1860-1919), zasłużonego historyka prawa i edytora, m.in. ksiąg sądowych.

13 Por. PSB 1, s. 245-248. Zob. też monografię M. Pyter, Oswald Balzer i lwowska szkoła historycznoprawna, Lublin 2010, passim.

${ }^{14}$ Por. artykuł Balzera Niemcy $w$ Polsce, opublikowany w Kwartalniku Historycznym 25, 1911, s. 439-444. Zob. też uwagi o wpływie Balzera na 
na ziemiach polskich rozgorzała nie tylko w gronie historyków prawa, ale również w środowisku mediewistów, gdzie toczyła się przez dziesiątki lat. Podobny do Oswalda Balzera nurt poglądów na rozwój miast reprezentowali Franciszek Bujak (1875-1953), historyk dziejów gospodarczych i społecznych oraz wybitny mediewista Kazimierz Tymieniecki (1887-1968), który dowodził ścisłej łączności między prawem niemieckim w Polsce oraz procesami feudalnymi na Zachodzie i Wschodzie Europy, a ponadto sformułował koncepcję tzw. miast na prawie polskim, rozwiniętą szeroko po $1945 \mathrm{r}^{15}$

Spośród prawników rzecznikiem tezy o ewolucji miast był poznański historyk państwa i prawa oraz znany niemcoznawca Zdzisław Kaczmarczyk (1911-1980) ${ }^{16}$. Uczony, który rozpoczął swoje badania jeszcze w dwudziestoleciu międzywojennym, traktował i przedstawiał kolonizację niemiecką w Polsce przede wszystkim jako element podobnych procesów feudalnych w Europie ${ }^{17}$.

historiografię: R. Nowacki, Oswald Balzer (1858-1933), Opole 1998, s. 169-172.

15 Por. Z. Wielgosz, Wstęp. Kazimierz Tymieniecki-Człowiek i dzieło Twórca nowoczesnej mediewistyki polskiej, [w:] K. Tymieniecki, Z dziejów miast i mieszczaństwa w późnośredniowiecznej Wielkopolsce, Poznań 2007, s. 9-33 (podane opracowanie zawiera wybór prac Tymienieckiego). Aktualne spojrzenie na dzieje i skutki lokacji por. M. Bogucka, H. Samsonowicz, Dzieje miast i mieszczaństwa $w$ Polsce przedrozbiorowej, Wrocław-Warszawa-Kraków-Gdańsk-Łódź 1986, s. 45-62.

16 Por. J. Wąsicki, Zdzisław Kaczmarczyk (1911-1980), Czasopismo Prawno-Historyczne 1981, t. XXXII, z. 2, s. 191-200; H. Olszewski, Zdzisław Kaczmarczyk 1911-1980, Poznań 2005. Por. prace Kaczmarczyka: Kolonizacja niemiecka na wschód od Odry, Poznań 1945; Kolonizacja niemiecka i kolonizacja na prawie niemieckim $w$ średniowiecznej Polsce, [w:] Stosunki polsko-niemieckie $w$ historiografii, cz. 1, Poznań 1974, s. 218-326; Początki miast polskich. Zagadnienia prawne, Czasopismo Prawno-Historyczne 1961, t. XIII, z. 2, s. 9-45 - jest to rozprawa fundamentalna dla historyków prawa zajmujących się historią i instytucjami prawnymi dawnych miast. Ponadto Kaczmarczyk (wraz z A. Wędzkim) zredagował: Studia nad początkami i rozplanowaniem miast nad środkową Odrą i Dolna Warta, t. 1-2, Zielona Góra 1967-1970.

17 W dwudziestoleciu międzywojennym badania rozpoczęli, obok Kaczmarczyka, historycy Stanisław Pazyra (wykładowca Uniwersytetu we Lwowie) oraz Karol Maleczyński (późniejszy profesor we Wrocławiu). 
Po II wojnie światowej, w związku z obowiązkowym przyjęciem w nauce filozofii materialistycznej oraz $z$ powodu faktycznej likwidacji, już w latach 40. XX w., swobody badań naukowych, wielu historyków prawa, zwłaszcza tych poszukujących bezpieczniejszych nisz naukowych, zwróciło się ku historii Polski oraz dziejom średniowiecza $^{18}$. $Z$ tej to między innymi przyczyny badania historycznoprawne okresu PRL-u zanotowały znaczące osiągnięcia ${ }^{19}$. Chociaż w Polsce Ludowej przez kilka dziesiątków lat toczyła się nadal intensywna dyskusja naukowa nad pochodzeniem (niemieckim czy rodzimym) miast na terytorium państwa polskiego, historycy prawa generalnie nie angażowali się w tę debatę ${ }^{20}$.

\section{Badania w Uniwersytecie Jagiellońskim}

Uczeni, którzy na Wydziale Prawa UJ podjęli najbardziej owocne studia nad dawnym prawem niemieckim, byli jeszcze nierzadko wychowankami uczniów krakowskiej szkoły historycznej. Ludwik

18 S. Grodziski, Wspomnienia z lat czterdziestych i pięćdziesiatych $X X$ wieku, [w:] Drogi i bezdroża nauk historycznoprawnych, red. M. Małecki, Bielsko-Biała 2010, s. 27-37. Autor wspomnień notuje, że ku problematyce średniowiecznej zwracali się niekiedy przedstawiciele dogmatycznych dyscyplin prawnych, na przykład Ludwik Ehrlich porzucił prawo międzynarodowe, by pisać o Pawle Włodkowicu.

19 Motywy, rozkład i rezultaty tych badań były jednak dość zróżnicowane. Por. dla ilustracji sytuację na wydziałach prawa w Poznaniu, Wrocławiu i Krakowie: Zarys dziejów Wydziału Prawa Uniwersytetu w Poznaniu 1919-2004, red. K. Krasowski, Poznań 2004, s. 119-131; K. Nowacki, Zarys dziejów prawa na Uniwersytecie Wrocławskim, Wrocław 2003, s. 209-226; S. Salmonowicz, Jak studiowałem $w$ dobie polskiego stalinizmu, Analekta 11: 2002, z. 1-2, s. 313-336.

20 Po II wojnie światowej ewolucyjną i rodzimą koncepcję rozwoju miast reprezentowali m.in. Gerard Labuda, Aleksander Gieysztor, Stanisław Piekarczyk, Anna Rutkowska-Płachcińska. Weryfikacji poddawali ją historycy z Henrykiem Samsonowiczem, Karolem Buczkiem i Benedyktem Zientarą na czele. Por. fundamentalną, chociaż nie pierwszą, rozprawę tego ostatniego: Źródła i geneza „prawa niemieckiego” na tle ruchu osadniczego $w$ Europie zachodniej $i$ środkowo-wschodniej $w$ XI $i$ XII $w$., Przegląd Historyczny 1978 , t. 69 , z. 1 , s. $47-74$. 
Łysiak (1923-2002) ${ }^{21}$ oraz Wacław Uruszczak (ur. 1946) ${ }^{22}$ kontynuowali dzieło swego mistrza profesora Adama Vetulaniego (1901-1976) ${ }^{23}$. Za ucznia Adama Vetulaniego uważał się także romanista i badacz wpływów rzymskich w prawie dawnej Polski Wiesław Litewski (1933-2004) ${ }^{24}$. Janusz Sondel (ur. 1937) ${ }^{25}$, wychowanek profesora Wacława Osuchowskiego, osiągnął znaczące sukcesy w opracowaniu wpływów romanistycznych w prawach miejskich. Lesław Pauli (1919-1986) ${ }^{26}$ oraz Irena Malinowska-Kwiatkowska (1925-1994) ${ }^{27}$, uczniowie Michała Patkaniowskiego ${ }^{28}$ (wychowanka słyn-

21 J. Malec, Ludwik Łysiak (1923-2002), Czaopismo Prawno-Historyczne 2003, t. LV, z. 1, s. 507-509; W. Uruszczak, Badacz i wydawca źródeł prawa dawnej Polski. Czterdzieści pięć lat pracy naukowej Profesora Ludwika Łysiaka, [w:] Studia z dziejów państwa i prawa polskiego Uniwersytetu Łódzkiego, t. 5, Łódź-Kraków 2000, s. 5-13.

22 Por. życiorys naukowy Profesora Uruszczaka pióra S. Grodziskiego: Wacław Uruszczak - prawnik $i$ historyk, [w:] Vetera novis augere. Studia i prace dedykowane Profesorowi Wacławowi Uruszczakowi, t. 1, Kraków 2010, s. XXI-XXV; tu także, na s. XXXIII-LVII Spis prac naukowych i popularnonaukowych Profesora dra hab. Wacława Uruszczaka, zestawiony przez Z. Zarzyckiego.

23 Por. S. Grodziski, Adam Vetulani (1901-1976), Czasopismo Prawno-Historyczne 1977, t. XXIX, z. 1, s. 153-161; W. Uruszczak, Adam Joachim Vetulani (1901-1976), [w:] Uniwersytet Jagielloński. Złota Księga, s. 393-399 .

24 J. Reszczyński, Wiesław Litewski (1933-2004), Czasopismo Prawno-Historyczne 2005, t. LVII, z. 1, s. 443-448.

25 W. Uruszczak, P. Święcicka, A. Kremer, Pro Patria et Scientia Vivere. 50 lat pracy naukowej Profesora Janusza Sondla, [w:] Leges sapere: studia i prace dedykowane Profesorowi Januszowi Sondlowi w pięćdziesiątą rocznicę pracy naukowej, red. W. Uruszczak, P. Święcicka, A. Kremer, Kraków 2008, s. 17-33.

26 I. Malinowska-Kwiatkowska, Lesław Pauli (1919-1986), Czasopismo Prawno-Historyczne 1986, t. XXXIX, z. 1, s. 232-235.

27 K. Baran, Irena Malinowska-Kwiatkowska (1925-1994), Czasopismo Prawno-Historyczne 1995, t. XLVII, z. 1-2, s. 303-304.

28 M. Patkaniowski (1907-1972) zapisał się jako autor monografii poświęconej najważniejszemu organowi miejskiemu dawnego Krakowa, zatytułowanej Krakowska rada miejska w wiekach średnich, Kraków 1934. 
nego Stanisława Estreichera ${ }^{29}$ ), badali dorobek polskich pisarzy prawa sasko-magdeburskiego.

Do największych osiągnięć historyków prawa UJ w zakresie badań nad dawnym prawem miejskim należą niewątpliwie studia nad Sądem Wyższym Prawa Magdeburskiego na Zamku Krakowskim, rolą prawa magdeburskiego w rozwoju polskiej jurysprudencji oraz wpływami romanistycznymi w dawnym prawie miejskim i jego nowożytnych kodyfikacjach.

Monografii najwyższego sądu prawa magdeburskiego w Krakowie oraz dwutomowego wyboru jego orzeczeń dostarczył profesor Ludwik Łysiak. Profesor L. Łysiak był już wytrawnym historykiem prawa oraz doświadczonym archiwistą i zasłużonym wydawcą licznych źródeł prawa ziemskiego i wiejskiego, kiedy w latach 80. podjął współpracę z Instytutem Europejskiej Historii Prawa im. Maxa Plancka we Frankfurcie nad Menem ${ }^{30}$. Jej rezultatem stała się opublikowana w 1990 r. w języku niemieckim monografia Ius supremum Maydeburgense castri Cracoviensis ${ }^{31}$. Jak wiadomo, Sąd Wyższy Prawa Magdeburskiego został utworzony w 1356 r. na Zamku Krakowskim przez Kazimierza Wielkiego jako sąd leński dla wójtów i sołtysów, a zarazem jako sąd odwoławczy dla ludności poddanej prawu niemieckiemu. Król zbudował w ten sposób najwyższą instancję, rozpatrującą odwołania od wyroków sądów niż-

Por. S. Salmonowicz, Michat Patkaniowski (1907-1972). Przyczynek do dziejów Wydziału Prawa i Administracji UJ, [w:] idem, W cieniu Klio i Temidy. Studia z historii prawa, Toruń 2011, s. 105-139.

${ }^{29}$ Stanisław Estreicher (1869-1939) był historykiem prawa, profesorem i rektorem Uniwersytetu Jagiellońskiego. Por. S. Waltoś, Stanisław Estreicher (1869-1939), [w:] Uniwersytet Jagielloński. Złota Księga, s. 261-274. S. Estreicher opublikował m.in. źródła oraz opracowania na temat prawa magdeburskiego i chełmińskiego. Por. jego biografię i wykaz publikacji drukowanych, pióra W.M. Bartla, zawarte w t. 1 Studia Culmensia (por. przypis 82), dedykowanym profesorowi Estreicherowi.

30 www.rg.mpg.de (dostęp: 4.04.2012 r.).

${ }^{31}$ Ius supremum Maydeburgense castri Cracoviensis 1356-1794. Organisation, Tätigkeit und Stellung des Krakauer Oberhofs in der Rechtsprechung Altpolens, Frankfurt am Main 1990. 
szych, które wcześniej kierowano wprost do Magdeburga ${ }^{32}$. Sąd przetrwał cztery stulecia, zmieniając częściowo skład, kompetencje i właściwość terytorialną. Profesor L. Łysiak w swej monografii wszechstronnie wyjaśnił, w jakich okolicznościach doszło do erygowania sądu, jaką organizację przybrał ten szczególny trybunał, jaką miał właściwość i wreszcie - jak funkcjonował. Książka spotkała się z bardzo wysoką oceną znawców przedmiotu ${ }^{33}$. Następnie Ludwik Łysiak, wspólnie $z$ niemiecką prawniczką i historyczką prawa Karin Nehlsen-von Stryk, opracował dwa obszerne tomy dekretów sądu krakowskiego, wydanych w XV-XVI wieku w związku $z$ apelacjami sądów niższej instancji ${ }^{34}$. To monumentalne wydawnictwo otrzymało również bardzo pochwalne recenzje ${ }^{35}$, a nawet nagrodę polskiego premiera (1998).

Należy podkreślić, że badania źródłoznawcze są na Wydziale Prawa i Administracji UJ kontynuowane. Uprawia je nadal przede wszystkim profesor Wacław Uruszczak, wydawca ksiąg sądowych ${ }^{36}$, a zarazem znawca dawnej nauki prawa, w tym historiografii prawa miejskiego. Profesor W. Uruszczak upowszechnił wiedzę o dorobku polskich prawników i historyków prawa, w tym uczonych i prakty-

32 Jako trzecią i najwyższą instancję prawa miejskiego powołano Sąd Sześciu Miast (Krakowa, Kazimierza, Bochni, Wieliczki, Sącza, Olkusza).

33 Por. recenzje: J. Matuszewski, Ius Teutonicum - ius ignotum, Czasopismo Prawno-Historyczne 1992, t. XLIV, z. 1-2, s. 169-173; J. Wyrozumski, O Sadzie Najwyższym Prawa Niemieckiego na Zamku Krakowskim, Czasopismo Prawno-Historyczne 1992, t. XLIV, z. 1-2, s. 173-177; W. Uruszczak, Ludwik Łysiak, Ius supremum Maydeburgense castri Cracoviensis 1356-1794, Revue historique de droit français et étranger (dalej: RHD) 1991, t. 69, s. 381-382.

34 Decreta Iuris Supremi Magdeburgensis. Die Rechtsprüche des Oberhofs des deutschen Rechts auf der Burg Krakau, Bd. 1: 1456-1481, Bd. 2: 1481-1511, Frankfurt am Main 1995-1997.

35 Por. recenzję najlepszego niemieckiego znawcy prawa magdeburskiego Friedricha Ebla (1944-2005), ZRG GA 116 (1999), s. 687-688 oraz opublikowaną we Francji recenzję Stanisława Salmonowicza: RHD 1995, t. 73, z. 3, s. 388-389; 1998, t. 76, z. 1, s. 297.

36 Por. najważniejsze edycje ksiąg sądu kryminalnego w Wiśniczu: Acta Maleficorum Wisniciae (1629-1665), Kraków 2003 oraz Acta Nigra Maleficorum Wisniciae (1665-1785), Kraków 2010. 
ków opracowujących prawo miejskie, w licznych wydawnictwach krajowych i zagranicznych ${ }^{37}$.

Dorobek pisarzy prawa miejskiego oraz miejskie i regionalne ustawodawstwo stały się przedmiotem badań, prowadzonych w różnych aspektach przez profesorów Lesława Paulego i Janusza Sondla oraz - w mniejszym stopniu - przez profesora Wiesława Litewskiego i profesor Irenę Malinowską-Kwiatkowską.

Lesław Pauli dał syntetyczny obraz polskiej literatury prawa magdeburskiego $\mathrm{w}$ XVI wieku ${ }^{38}$ oraz szczegółowe opracowanie na temat Jana Cezaryna Kirsteina, wójta Sądu Wyższego Prawa Magdeburskiego na Zamku Krakowskim ${ }^{39}$. Irena Malinowska-Kwiatkowska zajmowała się wpływami prawa magdeburskiego w twórczości polskich prawników XVII w. ${ }^{40}$ Wiesław Litewski, w ramach swego obszernego opracowania kodyfikacji wschodniopruskiej z XVII w., prześledził późną historię obowiązującego w Prusach

37 Por. biogramy pióra W. Uruszczaka zamieszczone w leksykonach: Juristen. Ein biographisches Lexicon. Von der Antike bis zum 20. Jahrhundert, wyd. M. Stolleis, München 1994; Nation and History. Polish historians from the Enlightenment to Second World War, wyd. P. Brock, J.D. Staley, P.J. Wróbel, Buffalo-Toronto-London 2006.

38 Die polnische Literatur des Magdeburger Rechts im 16. Jahrhundert, [w:] Studien zur Geschichte des sächsisch-magdeburgischen Rechts in Deutschland und Polen (Rechtshistorische Studien, Bd. 10), wyd. D. Willoweit, W. Schich, Frankfurt am Main-Bern-Cirencester UK 1980, s. 150-162 .

39 Jan Kirstein Cerasinus (1507-1561), krakowski prawnik doby Odrodzenia. Studium $z$ dziejów praw obcych i literatury prawniczej $w$ Polsce, Kraków 1971.

40 Das sächsische Recht in der polnischen juristischen Literatur des 17. Jahrhunderts, [w:] Deutsches Recht zwischen Sachsenspiegel und Aufklärung. Rolf Lieberwirth zum 70. Geburtstag, wyd. G. Lingelbach, H. Lück, Frankfurt am Main 1991, s. 119-123; Die Stellung des sächsisch-magdeburgischen Rechts in der Normenhierarchie nach den Anschauungen polnischer Juristen des 16. und 17. Jahrhunderts, [w:] wyd. D. Willoweit, W. Schich, op.cit., s. 145-149; Bemerkungen über das Culmer Strafrecht vom 16. Jahrhunder, [w:] Mestske pravo v 16.-18. stoleti $v$ Evrope, Praha 1982 , s. 157-169. 
Wschodnich prawa chełmińskiego ${ }^{41}$. Janusz Sondel zbadał i opracował wpływy romanistyczne w prawie miejskim, w tym u słynnego prawnika Bartłomieja Groickiego, który był zarazem pisarzem krakowskiego sądu ${ }^{42}$. Ponadto $w$ wielu pracach monograficznych uczony przedstawił szeroki zakres recepcji prawa rzymskiego w szesnastowiecznych kodyfikacjach prawa chełmińskiego ${ }^{43}$. Niezależnie od tych cenionych w kraju i za granicą studiów profesor J. Sondel, wspólnie $z$ panią profesor Ireną Malinowską-Kwiatkowską, wydał polski przekład jednej ze znanych i stosowanych w praktyce sądowej kodyfikacji prawa chełmińskiego ${ }^{44}$.

41 Landrecht des Herzogtums Preußen von 1620, Bd. 1-5, Warszawa-Kraków 1982-1987.

42 O poczatkach recepcji prawa rzymskiego $w$ polskim prawie miejskim, Zeszyty Naukowe Uniwersytetu Jagiellońskiego. Prace prawnicze 97: 1982, s. 37-53; Elementy prawa rzymskiego $w$ miejskim prawie karnym $w$ dawnej Polsce, [w:] Profesorowi Janowi Kodrębskiemu in memoriam, red. A. Pikulska-Robaszkiewicz, Łódź 2000, s. 375-398. Co do Groickiego - por. przypis 101.

43 Najważniejszym opracowaniem jest książka Studia nad prawem rzymskim w „Jus Culmense” (W 750-lecie wydania przywileju chełmińskiego), Zeszyty Naukowe Uniwersytetu Jagiellońskiego 717. Prace prawnicze 1984, t. 109. Doczekała się ona kilku pozytywnych recenzji, na łamach Czasopisma Prawno-Historycznego 1986, t. XXXIX, z. 1; ZSS RA 1986; Komunikatów Mazursko-Warmińskich 1: 1987 oraz ZSS GA 1988. Z mniejszych rozpraw na uwagę zasługują: Elementy romanistyczne $w$ rewizjach prawa chełmińskiego: lidzbarskiej (1566), nowomiejskiej (1580) i toruńskiej (1594), Toruń 1988; Elemente des römischen Rechts in den Kodifikationen des Kulmer Rechts, [w:] Ius Commune 1993, z. 20, s. 25-60; Paweł Kuszewicz i jego tłumaczenie rewizji nowomiejskiej prawa chełmińskiego, [w:] Historia prawa - historia kultury. Liber Memorialis Vitoldo Maisel dedicatus, red. E. Borkowska-Bagieńska, H. Olszewski, Poznań 1994, s. 263-289; Leges sumptuariae $w$ rewizji toruńskiej prawa chełmińskiego - twór samodzielny czy recypowany, Acta Universitatis Nicolai Copernici (dalej: AUNC). Prawo 1990, z. 30, s. 57-68.

44 Rewizja nowomiejska prawa chełmińskiego z 1580 (1814), zwana także Jus Culmense Emendatum lub Jus Culmense Polonicum, Toruń 1993. Źródło to ukazało się w ramach zainicjowanych i koordynowanych przez Profesora Zbigniewa Zdrójkowskiego w Toruniu interdyscyplinarnych badań nad prawem chełmińskim. Por. przypisy 78-81. 
W związku z badaniami nad prawem magdeburskim krakowscy historycy prawa nawiązali kontakty naukowe $z$ uczonymi niemieckimi, głównie $z$ Wolnego Uniwersytetu w Berlinie. Rezultatem tej współpracy naukowej stała się konferencja na temat prawa sasko-magdeburskiego w Niemczech i Polsce, zorganizowana w 1977 r. w Krakowie. W 1980 r. ukazał się bardzo wartościowy, chociaż niewielki, tomik pokonferencyjny, w którym swoje rozprawy opublikowało pięciu niemieckich i pięciu polskich uczonych ${ }^{45}$.

\section{Badania w Uniwersytecie im. Adama Mickiewicza w Poznaniu}

Tradycja badań nad historią miast i prawa miejskiego sięga w Poznaniu okresu międzywojennego. W owym czasie na poznańskim Uniwersytecie czynni byli m.in. wspomniany już wyżej profesor Kazimierz Tymieniecki, zasłużony mediewista ${ }^{46}$, oraz Zygmunt Wojciechowski (1900-1955) ${ }^{47}$, historyk państwa i jego ustroju, wykształcony we Lwowie. Obydwaj uczeni wznowili po II wojnie światowej swą działalność w Poznaniu, rozwijając wcześniejsze

45 Wydany przez D. Willoweita i W. Schicha - por. przypis 38. W tomiku rozprawy umieścili profesorowie: Ludwik Łysiak, Irena Kwiatkowska, Lesław Pauli z UJ, Witold Maisel z UAM oraz Krystyna Bukowska-Gorgoni, romanistka wywodząca się z Wydziału Prawa Uniwersytetu Warszawskiego, ówczesna współpracowniczka Instytutu Europejskiej Historii Prawa we Frankfurcie nad Menem. Warto dodać na marginesie, że Bukowska była autorką kilku studiów na temat recepcji prawa rzymskiego w dawnym prawie miejskim, m.in. Orzecznictwo krakowskich sądów wyższych w sporach o nieruchomości miejskie $w$ XVI-XVII $w$. Studium z historii prawa rzymskiego $w$ Polsce, Warszawa 1967; O recepcji prawa rzymskiego $w$ prawie miejskim $w$ dawnej Polsce, Czasopismo Prawno-Historyczne 1968, t. XX, z. 1, s. 71-92.

46 Por. przypis 15.

47 Por. H. Olszewski, Zygmunt Wojciechowski-Poznańska szkoła historii prawa, Ruch Prawniczy, Ekonomiczny i Socjologiczny 1994, t. 56, z. 3, s. 18-23. Por. kontrowersyjną w swych ocenach monografię niemiecką: M. Krzoska, Für ein Polen an Oder und Ostsee. Zygmunt Wojciechowski (1900-1955) als Historiker und Publizist, Osnabrück 2003. 
badania. Profesor Wojciechowski był zwolennikiem ideograficznej koncepcji dziejów i od 1945 r. reprezentował i bronił koncepcji tzw. ziem macierzystych Polski. Wśród jego uczniów znaleźli się m.in. Józef Matuszewski (w Poznaniu, potem w Łodzi) oraz Michał Sczaniecki (w Warszawie), o których mowa poniżej.

Po II wojnie światowej kierunki badań nad dawnym prawem niemieckim na Wydziale Prawa UAM objęły przede wszystkim edycję i opracowanie źródeł, zwłaszcza tych obowiązujących w Poznaniu i regionie, a ponadto ustrój sądowy i prawo miast wielkopolskich, lokowanych zgodnie ze wzorcem magdeburskim. Niewątpliwie największe zasługi na obu tych polach położył profesor Witold Maisel (1914-1993) ${ }^{48}$, który był uczniem m.in. wspomnianego wyżej Zdzisława Kaczmarczyka ${ }^{49}$.

Profesor W. Maisel opublikował bogate źródła: najpierw ortyle wyższych sądów miast wielkopolskich ${ }^{50}$, następnie poznańską księgę prawa ${ }^{51}$, a potem trzytomowy wybór wilkierzy, wydawanych przez władze Poznania ${ }^{52}$. Niezależnie od publikacji tak licznych orzeczeń sądowych, ksiąg i ustaw miejskich uczony wydał także fundamentalne przywileje miasta Poznania ${ }^{53}$, lokowanego w $1253 \mathrm{r}$.

48 J. Sobczak, Witold Maisel (1914-1993), Czasopismo Prawno-Historyczne 1995, t. XLVII, z. 1-2, s. 299-301. Por. A. Gulczyński, Bibliografia prac naukowych profesora Witolda Maisla, [w:] Historia prawa - Historia kultury, s. 15-37.

49 Por. przypis 16.

50 Ortyle sądów wyższych miast wielkopolskich z XV i XVI wieku, [w:] Starodawne Prawa Polskiego Pomniki, Seria 2, Dział 3: Prawo miejskie, t. 1, Wrocław 1959.

51 Poznańska księga prawa magdeburskiego i miśnieńskiego, [w:] Starodawne prawa polskiego pomniki. Seria 2. Pomniki prawa polskiego. Dział 3: Prawo miejskie, t. 2, Wrocław-Warszawa-Kraków 1964.

52 Wilkierze poznańskie (Statuta civitatis Posnaniensis), t. 1-3, [w:] Starodawne prawa polskiego pomniki. Seria 2. Pomniki prawa polskiego. Dział 3: Prawo miejskie, Wrocław-Warszawa-Kraków 1966-1969.

53 Kodeks przywilejów Poznania z XIV wieku, Studia i Materiały do Dziejów Wielkopolski i Pomorza 1980, t. 13, z. 2. Już po śmierci Profesora Maisla zostały opublikowane Jego Przywileje miasta Poznania XIII-XVIII wieku, Poznań 1994. 
na prawie magdeburskim (z licznymi odchyleniami). Profesor W. Maisel zasłużył się również jako wydawca źródeł innych miast, w tym m.in. przywilejów bądź wilkierzy Kalisza, Konina, Chodzieży, Pleszewa. Niezależnie od swej pracy edytorskiej, bardzo wiele uwagi poświęcił badaniu dawnej praktyki wymiaru sprawiedliwości w sprawach karnych, rozwiniętej w stolicy Wielkopolski. Pierwszą znaczącą pracą była tu książka o sądach poznańskich ${ }^{54}$, drugą monografia przedstawiająca prawo karne stosowane w dawnym Poznaniu ${ }^{55}$. Ta ostatnia praca w niezwykle interesujący sposób ukazała, jak na przestrzeni wieków obowiązujące w mieście prawo magdeburskie wchłaniało elementy prawa rzymskiego, a nawet kanonicznego i polskiego. Taka prezentacja nie miała i nie ma sobie równych w polskiej literaturze historycznoprawnej.

\section{Badania w Uniwersytecie Eódzkim}

W centrum zainteresowań naukowych historyków prawa Uniwersytetu Łódzkiego, założonego w 1945 r., znajdowały się i po dziś dzień się znajdują badania źródłoznawcze. Obejmowały one i nadal obejmują przede wszystkim przywileje lokacyjne oraz teksty Zwierciadła Saskiego, najbardziej szanowanego i popularnego w Europie niemieckiego pomnika prawnego, stosowanego na ziemiach polskich do końca XVIII w. ${ }^{56}$ Ogromne zasługi w tych dziedzinach położyli profesorowie Józef Matuszewski oraz Zygfryd Rymaszewski.

W zakresie historii osadnictwa niemieckiego oraz dokumentów lokacyjnych nie do przecenienia jest dorobek profesora Józefa Matuszewskiego (1911-2003), znawcy dziejów prawa i gospodarki, mediewisty, wykładowcy uniwersytetu poznańskiego, a następnie

54 Sąownictwo miasta Poznania do końca XVI wieku, Poznań 1961.

55 Poznańskie prawo karne do końca XVI wieku, Poznań 1963. Za opracowaniem tym poszły kolejne $z$ zakresu prawa miejskiego, a zwłaszcza miejskiego prawa karnego, m.in. Das Strafrecht in den Willküren der polnischen Städte bis zum Ende des 18. Jahrhunderts, Archivum Iuridicum Cracoviense 1975, t. 8, s. 55-76; Die Quellen des deutschen Rechts im mittelalterlichen Posen, [w:] wyd. D. Willoweit, W. Schich, op.cit., s. 116-121.

56 Por. przypis 2. 
łódzkiego ${ }^{57}$. Należy powtórzyć, że Józef Matuszewski był uczniem wspomnianych wyżej profesorów poznańskich Zygmunta Wojciechowskiego oraz Kazimierza Tymienieckiego.

Profesor J. Matuszewski zapisał się jako niestrudzony i wnikliwy badacz średniowiecznych dokumentów, na podstawie których dostarczał licznych przyczynków do historii lokacji miast i zwłaszcza wsi. W swych tekstach dowodził różnic między kolonizacją niemiecką a zwykłym przenoszeniem osad na prawo niemieckie ${ }^{58}$. Ze szczególnym upodobaniem i pietyzmem studiował prawo wiejskie, przy czym analizy źródłowe doprowadziły go do wniosku, że polska wieś generalnie nie przejęła niemieckiego prawa sądowego, natomiast - pod bezpośrednim wpływem prawa miejskiego - stopniowo recypowała liczne elementy prawa sasko-magdeburskiego ${ }^{59}$. Profesor J. Matuszewski był także znawcą Zwierciadła saskiego, które analizował m.in. $z$ punktu widzenia elementów słowiańskich ${ }^{60}$.

Ogromny wkład do naukowej krytyki źródeł wniósł profesor Zygfryd Rymaszewski (ur.1927) ${ }^{61}$, uczeń m.in. profesorów Jana Adamusa, historyka państwa i prawa polskiego, i wspomnianego wyżej Józefa Matuszewskiego. Profesor Z. Rymaszewski skupił się w zakresie interesujących nas badań - na studiach nad przekładami Zwierciadła saskiego, rozpowszechnionymi w dawnej Polsce,

57 Por. Z. Rymaszewski, In memoriam. Józef Matuszewski (1911-2003), Czasopismo Prawno-Historyczne 2004, t. LVI, z. 1, s. 393-395.

58 Die Aufnahme des deutschen Rechtes in Polen, Bulletin de la Societe des Sciences et des Lettres de Łódź 1970, t. 20, z. 4, s. 1-11.

59 Prawo sacdowe na wsi polskiej lokowanej na prawie niemieckim, [w:] Studia z dziejów państwa i prawa polskiego, t. 2, Łódź 1995, s. 40-75; Die Namengebung an die deutschrechtlichen Siedlungen, Bulletin de la Societe des Sciences et des Lettres de Łódź 1972, t. 22, z. 1; Nazwy administracyjne osad lokowanych na prawie niemieckim, Łódź 1974.

60 Por. Artykuły słowiańskie Zwierciadła saskiego, Czasopismo Prawno-Historyczne 1948, t. I, s. 25-74 - rozprawę, w której analizie poddano pozycję prawną Słowian (Wendów) w Zwierciadle. W Czasopiśmie Prawno-Historycznym autor publikował przez dziesiątki lat, ostatni tekst wydając w t. LV, 2003, z. 2.

61 M. Rakowski, T. Szulc, Jubileusz Profesora Zygfryda Rymaszewskiego, Czasopismo Prawno-Historyczne 2000, t. LII, z. 1-2, s. 435-436. 
a także nad działalnością sądów królewskich w sprawach płynących z Gdańska, obdarzonego prawem chełmińskim ${ }^{62}$.

Łacińskie, stosowane w praktyce sądowej na ziemiach polskich, teksty części pierwszej Zwierciadła saskiego ${ }^{63}$ opublikował profesor Z. Rymaszewski w dwóch tomach. Pierwszy zawiera ów najznakomitszy pomnik prawa niemieckiego w najstarszych tłumaczeniach z języka niemieckiego na łacinę, sporządzonych w końcu XIII i połowie XIV w. (odpowiednio przez Konrada $z$ Opola oraz Konrada z Sandomierza), a ponadto $\mathrm{w}$ wersji, która ukazała się w słynnym polskim zbiorze praw z 1506 r. - Statucie Łaskiego ${ }^{64}$. Tom drugi przedstawia łacińską kompilację Zwierciadła saskiego, sporządzoną przez krakowskiego pisarza miejskiego Mikołaja Jaskiera, wyróżniającą się jasnością i zgodnością $z$ niemieckim oryginałem ${ }^{65}$. Jak wiadomo, ta ostatnia stała się - na podstawie decyzji króla Zygmunta I Starego z 1535 r. - oficjalnym źródłem prawa, znajdując zastosowanie w sądach miejskich i wiejskich na terenie całego $\mathrm{kraju}^{66}$. Oba opracowania profesora Z. Rymaszewskiego mają charakter krytycznej edycji źródeł - znajdujemy w nich interpretacje

62 Gdańsk był pierwotnie lokowany na prawie lubeckim, a na prawie chełmińskim - dopiero w 1346 r. Por. Historia Gdańska. Tom I do roku 1454, red. E. Cieślak, Gdańsk 1978, s. 276-279 i 355-358. Edmund Cieślak (1922-2007), historyk, pracownik PAN, był jednym z najwybitniejszych znawców dziejów Gdańska i miast pruskich.

63 Uczony słusznie zbadał tłumaczenie tylko części pierwszej Zwiercia$d ł a$, tj. prawo ziemskie (Landrecht), które uzyskało rozgłos i znaczenie poza Niemcami, pomijając część drugą, zawierającą prawo lenne.

64 Łacińskie teksty Landrechtu Zwierciadła Saskiego w Polsce. Versio Vratislaviensis, versio Sandomiriensis, Łaski, Wrocław-Warszawa-Kraków-Gdańsk 1975. Integralną częścią tej edycji są tablice konkordancyjne oraz zestawienie kilkudziesięciu wykorzystanych rękopisów. Por. recenzję pióra W. Maisla, Czasopismo Prawno-Historyczne 1977, t. XXIX, z. 1, s. 136-137.

65 Łacińskie teksty Landrechtu Zwierciadła Saskiego w Polsce. Jaskier tekst główny i noty marginesowe, Łódź 1985. Por. recenzję sporządzoną także przez W. Maisla, Czasopismo Prawno-Historyczne 1986, t. XXXVIII, z. 1, s. 224-225.

66 Warto przypomnieć, że Jaskier nie oparł się na dotychczasowych przekładach Zwierciadła, lecz sięgnął do nieznanej w Polsce tzw. Versio Vulgata, którą znakomicie przeredagował, zamieszczając w swym dziele, poza 
treści norm prawnych, zawartych w Zwierciadle, a także informacje o tym, jakie wzory służyły staropolskim tłumaczom, oraz wskazówki, w jakim zakresie przekłady łacińskie odbiegały od niemieckiego oryginału. Autor stwierdza po około stu różnic w każdej wersji Zwierciadła: wrocławskiej, dwóch sandomierskich, a także w wydawnictwie Łaskiego. Stawia tezę, że częściowo były to błędy, a częściowo celowe lub przypadkowe pominięcia tekstów. Dochodzi do konkluzji, że wydawnictwo Łaskiego było tłumaczeniem krytycznym i pionierskim, a Jaskiera - samodzielną kompilacją, a nie prostym przekładem.

Oprócz Zwierciadła saskiego profesor Z. Rymaszewski opublikował jeszcze, w wersji łacińskiej oraz w tłumaczeniu na język polski, nieznany zwód prawa chełmińskiego z przełomu XIV i XV w., zaopatrując go w obszerny wstęp historyczny ${ }^{67}$.

Innym kierunkiem badań profesora $Z$. Rymaszewskiego była praktyka sądów królewskich - Asesorii Koronnej i Sądu Relacyjnego - w sprawach wynikających $\mathrm{z}$ rozstrzygania sporów mieszczan gdańskich. Analiza kazusów płynących z Gdańska do Warszawy, dekretów wydanych przez sądy królewskie, a także innych dokumentów przyniosła ciekawy i barwny obraz praktyki wymiaru sprawiedliwości w wydaniu instancji gdańskich i sądów królewskich w czasach nowożytnych ${ }^{68}$.

samym źródłem, glosy oraz streszczenia kolejnych artykułów. Przedmiotem edycji profesora Rymaszewskiego jest tekst główny Jaskiera oraz jego noty marginalne (lecz bez glos).

${ }^{67}$ Nieznany spis prawa chełmińskiego z przełomu XIV i XV w., Łódź 1993. Uczony udowadnia, że przepisy tego zwodu pochodziły ze zbioru pouczeń prawnych Magdeburga dla Wrocławia: Das Magdeburg-Breslauer systematische Schöffenrecht (około 40\%) z XIV w., względnie ze zbioru prawa starochełmińskiego: Der Alte Culm z końca XIV w. oraz z wyroków Sądu Wyższego w Chełmnie (około 60\%).

68 Sprawy gdańskie przed sąami zadwornymi oraz ingerencja królów $w$ gdański wymiar sprawiedliwości XVI-XVIII wieku, Wrocław-Warszawa-Kraków-Gdańsk-Łódź 1985. 


\section{Badania w Uniwersytecie Mikołaja Kopernika}

Toruń stał się - z racji położenia geograficznego i dzięki utworzeniu w tym mieście w 1945 r. uniwersytetu - naturalnym ośrodkiem badań nad prawem chełmińskim ${ }^{69}$, lokalną odmianą prawa miejskiego, opartą na przywileju dla Chełmna i Torunia z 1233 r. oraz orzecznictwie sądów magdeburskiego i chełmińskiego ${ }^{70}$. Zaczerpnięty $z$ Magdeburga wzorzec ustrojowy, dzięki przywilejowi dla Chełmna i Torunia rozpowszechnił się daleko poza granicami Ziemi Chełmińskiej, obejmując Kujawy, Ziemię Dobrzyńską, Mazowsze i Podlasie, a w niewielkim zakresie nawet Wielkopolskę, Małopolskę, Wołyń, Litwę i daleki Siedmiogród.

Największe i wyjątkowe zasługi w zakresie badań nad prawem chełmińskim na toruńskim Wydziale Prawa i Administracji położył profesor Zbigniew Zdrójkowski (1915-1995) ${ }^{71}$. Był on uczniem Stanisława Borowskiego (1903-1945) ${ }^{72}$, znawcy dawnego prawa polskiego, Józefa Rafacza (1890-1944) ${ }^{73}$, wybitnego specjalisty z zakresu ustrojów państwowych oraz prawa i procesu w dawnej Polsce, a przede wszystkim - Karola Koranyiego (1897-1964) jednego $z$ najwybitniejszych polskich historyków państwa i prawa XX w.

69 Tradycję badań nad prawem chełmińskim zapoczątkował u schyłku XVIII w. torunianin, prawnik, historyk i nauczyciel Krystian Bogumił Steiner - por. Stanisław Salmonowicz, Krystian Bogumił Steiner, toruński prawnik $i$ historyk. Studium $z$ dziejów nauki prawa doby Oświecenia $w$ Polsce, Toruń 1962.

70 Jednym z podstawowych źródeł prawa chełmińskiego był zbiór prawa magdebursko-wrocławskiego, wspomniany w przypisie 67.

${ }^{71}$ W latach 1951-1965 doktor (potem docent) Zdrójkowski był, u boku swego mistrza Karola Koranyiego, pracownikiem Wydziału Prawa Uniwersytetu Warszawskiego. Por. S. Salmonowicz, Zbigniew Zdrójkowski (1915-1995), Czasopismo Prawno-Historyczne 1994, t. XLVI, z. 1-2, s. 199-202.

72 G. Bałtruszajtys (red.), op.cit., s. 146-148.

73 Ibidem, s. 132-134; por. M. Janik-Terteka, Życie i twórczość Józefa Rafacza, Czarny Dunajec 2011.

74 S. Salmonowicz, Karol Koranyi (1897-1964). Szkic do portretu, [w:] idem, W cieniu Klio, op.cit., s. 93-104. 
Profesor Z. Zdrójkowski wniósł po pierwsze ogromny własny wkład naukowy w badania nad dawnym prawem miejskim; po drugie stworzył nieformalny, interdyscyplinarny zespół badaczy, którzy z okazji okrągłego jubileuszu 750-lecia wydania przywileju chełmińskiego, przypadającego w 1983 r., przygotowali i opublikowali rząd cennych źródeł oraz opracowań prawa chełmińskiego.

Profesor Z. Zdrójkowski zajął się prawem chełmińskim już na początku lat $60 .{ }^{75}$ Następnie, widząc ogromną rolę dziejową tego systemu prawa, przygotował syntetyczny, bogato ilustrowany Zarys dziejów prawa chełmińskiego 1233-1862 ${ }^{76}$. Nie stronił również od krytyki źródeł, publikując m.in. nieznany wilkierz chełmiński z XVI w. ${ }^{77}$

Jubileusz przywileju chełmińskiego stał się dla profesora Z. Zdrójkowskiego nie tylko okazją do zintensyfikowania własnych badań, ale także do pozyskania do współpracy, między innym dzięki umowie między miastem Chełmnem a UMK, szerokiego grona specjalistów - historyków oraz historyków prawa z Torunia, Poznania, Krakowa, Łodzi, Warszawy, Olsztyna i innych miast. Zakrojone na szeroką skalę prace przyniosły wiele spektakularnych efektów przede wszystkim serię wydawniczą Teksty pomników prawa chełmińskiego $w$ przekładach polskich pod redakcją Zbigniewa Zdrójkowskiego oraz monumentalne wydawnictwo Studia Culmensia Historico-Iuridica.

W ramach serii ukazał się fundamentalny dokument - przywilej chełmiński z 1233 r., którego oryginalny dyplom z 1251 r., stanowiący odnowiony akt lokacji dwóch głównych miast Ziemi Chełmińskiej, jest jednym $z$ najcenniejszych dokumentów pergaminowych

75 Korektura pruska, jej powstanie, dzieje oraz rola $w$ historii polskiej jurysdykcji i myśli prawniczej (1598-1830), Czasopismo Prawno-Historyczne 1961, t. XIII, z. 2, s. 109-157; Prawo chełmińskie, powstanie, rozwój i jego rola dziejowa, [w:] Dzieje Chełmna i jego regionu, red. M. Biskup, Toruń 1968.

76 Toruń 1983. Pierwszą próbą syntezy prawa chełmińskiego była rozprawa wskazana w przypisie 75 .

77 Nieznane źródła prawa chełmińskiego z XVI i XVII w. Część I, Czasopismo Prawno-Historyczne 1971, t. XXIII, z. 2, s. 141-182. Rozprawa ta obejmowała wilkierz Chełmna z 1590 r. - jego tekst oraz stosowny komentarz. 
przechowywanych w Archiwum Państwowym w Toruniu. Przywilej, poprzedzony wstępem edytorsko-historycznym i zaopatrzony w liczne ilustracje jego kopii i druków, został wydany przez pracownika naukowego Instytutu Historii i Archiwistyki UMK Krystynę Zielińską-Melkowską ${ }^{78}$. W tej samej serii ukazał się jeszcze najpopularniejszy pomnik prawa chełmińskiego Der Alte Kulm, skompilowany w końcu XIV w., a wydany drukiem w XVI w. w Toruniu ${ }^{79}$, a ponadto popularna kodyfikacja prawa chełmińskiego $\mathrm{z}$ XVI w. ${ }^{80}$ Zaplanowanej serii Teksty pomników prawa chełmińskiego $w$ przekładach polskich nie udało się, niestety, doprowadzić do końca ${ }^{81}$.

Owocem zbiorowego wysiłku były wydane przez profesora Z. Zdrójkowskiego dwa tomy rozpraw zatytułowanych Studia Culmensia Historico-Iuridica czyli Księga Pamiątkowa 750-lecia Prawa Chełmińskiego (dalej: Studia Culmensia), obejmujących blisko 1000

78 Przywilej chełmiński 1233 i 1251, Toruń 1986. Był to nr 1 Tekstów pomników prawa chełmińskiego $w$ przekładach polskich. Na marginesie wspomnieć trzeba, że w roku jubileuszu ukazała się jeszcze inna, bibliofilska edycja przywileju chełmińskiego w wersji pierwotnej i odnowionej, także w przekładach na język polski oraz ze stosownym wprowadzeniem historycznym, przygotowana przez toruńską historyczkę K. Ciesielską: Przywilej chełmiński 1233, 1251, Toruń 1983. Wydanie K. Zielińskiej-Melkowskiej było nie tylko odmienne, ale i bardziej popularne.

79 Prawo starochełmińskie 1584 (1394). Das alte coelmische Recht, (wyd.) W. Maisel, Z. Zdrójkowski, tłum. A. Bzdęga, A. Gaca, Toruń 1985. Był to nr 2 Tekstów.

80 Rewizja nowomiejska prawa chetmińskiego 1580 (1814). Por. przypis 44. Był to nr 6 Tekstów. Warto podkreślić znaczenie rewizji nowomiejskiej, która była stosowana przez wiele miast Prus Królewskich oraz królewski Sąd Asesorski, rozpatrujący apelacje od wyroków sądów miejskich.

81 Swoistą kontynuacją serii była jeszcze Rewizja lidzbarska prawa chetmińskiego 1566 (1711), Koszalin 1997, przygotowana z inspiracji profesora Zdrójkowskiego, zaplanowana jako nr 5 Tekstów, wydana ostatecznie samodzielnie przez Andrzeja Grota. $Z$ innych planowanych źródeł nie ukazały się: Dziewięć ksiag prawa magdeburskiego (planowany nr 3), Obiegowe prawo chełmińskie $z X V$ wieku (planowany nr 4), Ius Culmense revisum. Rewizja toruńska z 1594 r. (planowany nr 7), Korektura pruska z 1598 r. (planowany nr 8) oraz Wielki wilkierz miasta Torunia z 1634 i 1750 r. (planowany nr 9). 
stron druku. Tom pierwszy ${ }^{82}$ dostarczył przede wszystkim obszernego, historycznego wprowadzenia pióra redaktora (wraz z jego tłumaczeniem na 4 języki obce) oraz dziesięciu studiów poświęconych przywilejowi chełmińskiemu i jego roli historycznej, lokacjom miast i wsi na prawie chełmińskim, analizie wybranych treści prawa chełmińskiego oraz pierwszym opracowaniom prawa chełmińskiego ${ }^{83}$. Tom drugi ${ }^{84}$ zawierał osiem studiów, w których znalazły się opisy początków i rozwoju prawa chełmińskiego w Prusach Krzyżackich i Książęcych, a następnie w państwie prusko-brandenburskim, jak też w samym mieście Toruniu i na Mazowszu, a ponadto charakterystyka wybranych źródeł prawa miejskiego i chełmińskiego, $z$ uwzględnieniem elementów romanistycznych w tych źródłach, i wreszcie analiza chełmińskiego prawa karnego na wsi ${ }^{85}$. Oba tomy Studia Culmensia dały w sumie wszechstronny i ciekawy obraz genezy, rozwoju i późniejszych losów prawa chełmińskiego, a zarazem były i nadal są punktem wyjścia dla dalszych dociekań naukowych.

Jako doświadczony historyk prawa i świetny znawca prawa magdeburskiego podjął jeszcze profesor Z Z Zdrójkowski badania nad inną odmianą tego prawa - prawem średzkim. Uczony wskazywał na wyjątkowy charakter tego ostatniego prawa, opartego na pouczeniu prawnym ławników z Halle nad Soławą z 1235 r. ${ }^{86}$, a także na

82 Toruń 1990. Por. obszerną recenzję obu tomów: Z. Rymaszewski, O polskich studiach nad prawem chełmińskim, Zapiski Historyczne 1993, t. 58, z. 4, s. 103-120. Zob. też zagraniczne recenzje: tomu pierwszego Danuta Janicka, Ius commune. Zeitschrift für Europäische Rechtsgeschichte (dalej: Ius commune) 1992, t. 19, s.330-334; tomu drugiego J. Malec, Ius commune 1990, t. 17, s. 400-404.

83 Współautorami tomu byli: Janusz Bieniak, Marian Borzestowski, Antoni Czachorowski, Stanisław Estreicher, Maciej Gołembiowski, Krystyna Kamińska; Jerzy Luciński, Tadeusz Maciejewski, Wacław Odyniec, Lesław Pauli.

84 Toruń 1988. Tom drugi ukazał się zatem wcześniej niż tom pierwszy.

85 Współautorami tomu byli: Anna Borkiewicz-Celińska, Marian Borzestowski, Krystyna Kamińska, Ryszard Łaszewski, Tadeusz Maciejewski, Janusz Małłek, Stanisław Salmonowicz, Janusz Sondel.

86 Geneza prawa średzkiego i stopień jego odrębności w stosunku do innych form prawa niemieckiego stosowanych przy lokacjach są przedmio- 
ogromne znaczenie historyczne prawa średzkiego, na którym lokowano ponad sto miast, a łącznie $z$ osadami wiejskimi - ponad tysiąc miejscowości na terenie Śląska, Wielkopolski, Małopolski i Ziemi Sieradzko-Łęczyckiej. Bezpośrednim impulsem do bliższego zajęcia się prawem średzkim była dla profesora Z. Zdrójkowskiego okrągła, 750. rocznica uzyskania przez Środę Śląską pouczenia z Halle, przypadająca na rok 1985. Owocem badań profesora stał się rząd studiów, poświęconych przede wszystkim lokacjom osad targowych i klasztornych oraz miast na prawie średzkim ${ }^{87}$. Niestety, badania te nie zostały ukończone, a część zgromadzonych przez uczonego źródeł pozostała niewykorzystana.

Zainicjowane przez profesora Z. Zdrójkowskiego naukowe poszukiwania i opracowania były i są kontynuowane przez jego uczniów i współpracowników. Wychowanka profesora - profesor Krystyna Kamińska (1946-2010) - dostarczyła analizy sądownictwa w miastach lokowanych na prawie niemieckim ${ }^{88}$, a ponadto monografii o dziejach lokacji miejskich na prawie magdeburskim ${ }^{89}$. Profesor Ryszard Łaszewski (ur. 1941) zbadał wymiar sprawiedliwości we wsiach rządzących się prawem chełmińskim, prezentując organizację sądownictwa, a ponadto stosowane uregulowania karne

tem dyskusji w nauce. Por. K. Kamińska, Prawo średzkie jako instrument polityki osadniczej i gospodarczej w Polsce od XIII do początku XVI wieku, [w:] Historia integra. Księga pamiątkowa ofiarowana Prof. Stanisławowi Salmonowiczowi $w$ siedemdziesięciolecie urodzin, Toruń 2001, s. 147-160.

87 Stan badań nad problematyka prawa średzkiego. Studium na 750-lecie pouczenia miasta Halle dla Środy Ślaskiej, Czasopismo Prawno-Historyczne 1985, t. XXXVII, z. 2, s. 75-87; Prawo średzkie (1223-1511). Jego geneza, treść i rozprzestrzenienie, [w:] Z dziejów Środy Śląskiej, Środa Śląska 1985; Geneza prawa średzkiego i jego rola dziejowa (1223-1511), Acta Universitatis Wratislaviensis, nr 980. Historia 70, Wrocław 1990, s. 53-69; Lokacje osad targowych, klasztornych $i$ miast na prawie średzkim (1223-1477), ibidem, s. 215-242.

88 Sądownictwo miasta Torunia do połowy XVII wieku na tle ustroju sądów niektórych miast Niemiec i Polski, Warszawa-Poznań-Torun 1980. Por. również wspomniane wyżej (przypisy 83 i 85) rozprawy opublikowane Studia Culmensia, t. 1, s. 335-360 i t. 2, s. 23-84.

89 Lokacje miast na prawie magdeburskim na ziemiach polskich do 1370 r. Studium historycznoprawne, Torun 1990. 
i proceduralne ${ }^{90}$. Profesorowie Władysław Bojarski (1931-2000) i Zbigniew Naworski (ur. 1951) opracowali twórczość Jana Cervusa Tucholczyka, autora bardzo popularnego i wielokrotnie wznawianego w XVI w. dzieła $z$ zakresu prawa prywatnego ${ }^{91}$.

$Z$ inspiracji profesora Zdrójkowskiego na Wydziale Prawa i Administracji UMK powstał Zakład Historii Prawa Niemieckiego w Polsce, utworzony ad personam dla profesora Stanisława Salmonowicza (ur. 1931), który - usunięty z pracy z przyczyn politycznych - powrócił w 1982 r. na Uniwersytet. W tym niewielkim zakładzie, a późniejszej katedrze, prowadzone były i są nadal badania nad prawem chełmińskim $^{92}$. Profesor S. Salmonowicz, historyk państwa i prawa oraz niemcoznawca $z$ ogromnym dorobkiem naukowym, skupił swą uwagę na dziejach prawa chełmińskiego w czasach nowożytnych ${ }^{93}$. Wychowanka profesora Salmonowicza i zarazem jedna $z$ ostatnich uczennic profesora Zdrójkowskiego - profesor Danuta Janicka (ur. 1960) - zajęła się analizą chełmińskiego prawa i procesu karnego ${ }^{94}$,

90 Wymiar sprawiedliwości we wsiach województwa chełmińskiego $w$ XVII i XVIII $w$. Organizacja sądownictwa i postępowanie sądowe, Toruń 1974. Por. również wspomnianą wyżej (przypis 85) rozprawę opublikowaną w Studia Culmensia, t. 2, s. 365-435, a także monografię Wiejskie prawo karne $w$ Polsce XVII i XVII wieku, Toruń 1988, w której źródła pochodzenia magdeburskiego odgrywają ważną rolę.

91 Jan Jelonek Cervus $z$ Tucholi i jego twórczość prawnicza: ustrój sądów i prawo procesowe, Torun 1993.

92 Danuta Janicka, Der Lehrstuhl für die Geschichte des Deutschen Rechts in Polen an der Fakultät für Recht und Verwaltung der Nikolaus Kopernikus-Universität in Thorn, Inter Finitimos, Wissenschaftlicher Informationsdienst für deutsch-polnische Beziehungen 15/16, Osnabrück 1999, s.50-52.

93 De la réglamentation des coutumes et des moeurs bourgeoises á Toruń aux XVI-XVIII siècles, Studia Maritima 1981, t. 3, s. 115-128. Por. obszerną rozprawę $Z$ dziejów wschodniopruskich kodyfikacji prowincjonalnych (XVII-XIX w.). Przyczynek do losów prawa chełmińskiego $w$ państwie brandenbursko-pruskim, [w:] Studia Culmensia, t. 2, s. 271-326 (por. przypis 85).

94 Prawo karne $w$ trzech rewizjach prawa chełmińskiego z XVI w., Toruń 1992. Por. szereg mniejszych rozpraw, m.in. Wszczęcie postępowania karnego $w$ świetle trzech rewizji prawa chełmińskiego z XVI wieku, AUNC. Prawo 35: 1996, s. 89-114; Tryby postępowania $w$ sprawach o przestępstwa $w$ świetle trzech rewizji prawa chełmińskiego z XVI wieku, AUNC. 
a także dociekaniami nad znaczeniem wzorów magdeburskich dla Torunia i Chełmna ${ }^{95}$.

\section{Badania w Uniwersytecie Gdańskim}

Zakres prac badawczych prowadzonych przez historyków prawa Uniwersytetu Gdańskiego, utworzonego w 1970 r., objął z natury rzeczy przede wszystkim ustrój i prawo miast Pomorza Gdańskiego. Jest to wdzięczny obszar badawczy, pozwalający po pierwsze na ukazanie okoliczności i znaczenia fundamentalnej zmiany prawnej, jaką stanowiło przejście wielu miast, w tym Gdańska, od systemu prawa lubeckiego do ustroju i prawa chełmińskiego. Po drugie, ze względu na intensywną, lokalną działalność prawotwórczą miast pruskich (wielkich i mniejszych), owocne były i są badania nad rozwojem autonomicznego ustawodawstwa miejskiego (głównie nad wilkierzami), które przez kilka stuleci w znaczącym stopniu modyfikowało stosowane w praktyce prawo sądowe pochodzenia magdeburskiego.

Największy wkład w badania nad prawem miejskim Pomorza Gdańskiego wnieśli profesorowie Edwin Rozenkranz oraz Tadeusz Maciejewski.

Prawo 1996, t. 36, s. 83-106; Dowody $w$ procesie karnym $w$ świetle trzech rewizji prawa chełmińskiego z XVI wieku, [w:] Historia prawa - historia kultury, op.cit., s. 167-183.

95 Zur Bedeutung des Magdeburger Vorbilds in der städtischen Gerichtsbarkeit Nordpolens: Das Beispiel Kulm und Thorn, [w:] Gerichtskultur im Ostseeraum, H.-G. Knothe, M. Liebmann, Frankfurt am Main 2007, s. 29-40; Die Rezeption des Sachsenspiegels und des Magdeburger Rechts am Beispiel von Thorn im Kulmer Land, [w:] Rechts- und Sprachtransfer in Mittel- und Osteuropa. Sachsenspiegel und Magdeburger Recht, (red.) E. Eichler, H. Lück, Berlin 2008, s. 61-74; Zur Topographie der Städte des Magdeburger Rechts in Polen: das Beispiel Kulm und Thorn, [w:] Grundlagen für ein neues Europa. Das Magdeburger und Lübecker Recht in Spätmittealter und Früher Neuzeit, (red.) H. Lück, M. Puhle, A. Ranft, Köln-Weimar-Wien 2009, s. 67-81. 
Edwin Rozenkranz (1925-1992) ${ }^{96}$ należał do grona uczniów wspomnianego wyżej parokrotnie profesora Zdzisława Kaczmarczyka $^{97}$. Podobnie jak jego mistrz i nauczyciel nie był skłonny przeceniać roli napływowego elementu niemieckiego dla rozwoju miast na Pomorzu. Swój wysiłek badawczy skupił profesor E. Rozenkranz na początkach i ewolucji ustrojowej miast Pomorza Gdańskiego, przede wszystkim Gdańska. Najwięcej uwagi poświęcił jednak prawu lubeckiemu, którym w dawnej Polsce rządziły się m.in. Elbląg, Frombork i Braniewo, a pierwotnie również Gdańsk ${ }^{98}$.

Uczniem i następcą profesora Rozenkranza jest profesor Tadeusz Maciejewski (ur. 1952). Głównym przedmiotem jego opracowań naukowych jest aktywność prawotwórcza miast Prus Królewskich, która doprowadziła do znaczących przekształceń obowiązującego prawa chełmińskiego. Wyjątkowo bogate było w tym zakresie ustawodawstwo samego Gdańska, gdzie i w czasach krzyżackich i staropolskich wydano kilka wilkierzy oraz dziesiątki, a nawet setki ordynacji i rozporządzeń. Profesor T. Maciejewski zbadał i opisał nie tylko genezę oraz ewolucję prawa stanowionego w Gdańsku i innych miastach pruskich ${ }^{99}$, ale również konkretne rozwiązania czy instytucje prawa procesowego, prywatnego i karnego ${ }^{100}$. Udowodnił, że zwłaszcza osiemnastowieczne statuty miejskie wprowadzały wiele konstrukcji prawnych nieznanych prawu chełmińskiemu, a zapożyczonych z praw obcych, w tym prawa rzymskiego.

96 T. Maciejewski, Edwin Rozenkranz (1925-1992), Czasopismo Prawno-Historyczne 1994, t. XLVI, z. 1-2, s. 189-191.

97 Por. przypis 16.

98 Początki $i$ ustrój miast Pomorza Gdańskiego do schyłku XIV stulecia, Gdańsk 1962; Recepcja prawa lubeckiego $w$ miastach nadbałtyckich, Gdańsk 1967; Prawo lubeckie $w$ Gdańsku w latach 1261 /63-1346, Rocznik Gdański 25: 1966, s. 9-30; Prawo lubeckie $w$ Elblagu od XIII do XVI wieku, Rocznik Gdański 1991, t. 51, z. 1, s. 5-35.

99 Zbiory wilkierzy $w$ miastach państwa zakonnego do 1454 r. i Prus Królewskich lokowanych na prawie chełmińskim, Gdańsk 1989; Wilkierz królewskiego miasta Tczewa, Gdańsk 1994; Wilkierze miasta Torunia, Poznań 1997. Por. też obszerne rozprawy Tadeusza Maciejewskiego włączone do Studia Culmensia, t. 1 i 2 (zob. przypisy 83 i 85).

100 Obok monografii wymienionych w przypisie 99 - por. Prawo sadowe $w$ ustawodawstwie miasta Gdańska $w$ XVIII wieku, Wrocław 1984. 


\section{Badania w Uniwersytecie Warszawskim}

Historykom prawa związanym $z$ Warszawą zawdzięczamy nie tylko badania nad dziejami lokacji na prawie magdeburskim na Mazowszu oraz w Wielkim Księstwie Litewskim, ale nade wszystko upowszechnienie dorobku najznakomitszego i najbardziej płodnego staropolskiego autora dzieł prawniczych z zakresu prawa miejskiego - Bartłomieja Groickiego ${ }^{101}$. Ogromne zasługi dla krytyki i analizy źródeł położyli profesorowie Karol Koranyi, Juliusz Bardach i Stanisław Russocki.

Karol Koranyi (1897-1964) ${ }^{102}$, przedwojenny wykładowca Uniwersytetu Jana Kazimierza we Lwowie oraz późniejszy profesor historii prawa w Uniwersytecie Warszawskim (i przez pewien czas w Uniwersytecie Mikołaja Kopernika w Toruniu) wszedł do historiografii jako edytor cennych źródeł i badacz literatury prawa miejskiego. Uczony wydał i opatrzył komentarzami dzieła Bartłomieja Groickiego, pisarza Sądu Wyższego Prawa Magdeburskiego na Zamku Krakowskim, najważniejszego autora opracowań prawa magdeburskiego ${ }^{103}$. Profesor K. Koranyi, znając ogromne znaczenie dzieł Groickiego dla praktyki sądowej, w której były one traktowane do końca XVIII w. jak kodeksy prawne, wydał wszystkie główne prace pisarza, opatrując je stosownymi wstępami historycznymi ${ }^{104}$. Są one nieocenionym źródłem nie tylko dla historyków i historyków prawa, ale również $-z$ uwagi na język polski, w jakim zostały napisane - dla językoznawców. Ponadto profesor K. Koranyi dostarczył

101 D. Janicka, Groicki, Bartolomaeus (um 1534-1605), Handwörterbuch zur deutschen Rechtsgeschichte 2010, z. 11, s. 561-562. Mimo dużego postępu badań historycznoprawnych, w dalszym ciągu czekamy w Polsce na monografię poświęconą twórczości Groickiego.

102 K. Sójka-Zielińska, Karol Koranyi (1897-1964), [w:] G. Bałtruszajtys, op.cit., s. 237-239.

103 Porządek sądów i spraw miejskich prawa majdeburskiego (1953), Artykuły prawa majdeburskiego (1954), Porządek sądów około karania na gardle (1954), Tytuły prawa majdeburskiego (1954), Obrona wdów i sierot (1958).

104 Warszawa 1953-1958. 
kilku rozpraw poświęconych twórczości dawnych pisarzy, w tym wspomnianemu już wyżej Janowi Cervusowi Tucholczykowi ${ }^{105}$.

Następcą Karola Koranyiego na katedrze został Michał Sczaniecki (1910-1977) ${ }^{106}$, dotychczasowy profesor Uniwersytetu im. Adama Mickiewicza w Poznaniu, historyk państwa i prawa, znawca dziejów polskich i francuskich. W dorobku M. Sczanieckiego, ucznia Zygmunta Wojciechowskiego ${ }^{107}$, także nie zabrało opracowań $z$ zakresu dawnego prawa niemieckiego ${ }^{108}$. Natomiast historyk państwa i prawa polskiego Stanisław Russocki (1930-2002)109 opracował i opublikował m.in. studia $z$ dziejów lokacji miejskich na Mazowszu110.

Juliusz Bardach (1914-2010) ${ }^{111}$ był uczniem Stefana Ehrenkreutza (1880-1945), historyka prawa, profesora i ostatniego polskiego rektora Uniwersytetu Stefana Batorego w Wilnie, autora prac m.in. o dawnej Warszawie i prawie chełmińskim, na którym lokowano polską stolicę. W bogatej twórczości profesora J. Bardacha, najlepszego polskiego znawcy dziejów Litwy, znalazły się m.in. rozprawy $z$ historii miast lokowanych na prawie magdeburskim

105 Johannes Cervus Tucholiensis i jego dzieło ( $Z$ dziejów praw obcych i literatury prawniczej $w$ Polsce), Przewodnik Historyczno-Prawny 1931, z. 1. Por. przypis 91.

106 J. Bardach, H. Olszewski, Michał Sczaniecki (1910-1977), Czasopismo Prawno-Historyczne 1978, t. XXX, z. 1, s. 1-18. Por. ibidem (s. 19-39) bibliografię prac Sczanieckiego zestawioną przez Huberta Izdebskiego i Marka Wąsowicza.

107 Por. przypis 47.

108 Kolonizacja na prawie niemieckim $w$ Polsce a rozwój renty feudalnej, Czasopismo Prawno-Historyczne 1951, t. III, s. 59-86 (wspólnie z Z. Kaczmarczykiem).

109 A. Rosner, Stanisław Russocki (1930-2002), [w:] G. Bałtruszajtys, op.cit., s. 273-274.

110 Etapy lokacji miejskich na Mazowszu w XIV-XV wieku, Przegląd Historyczny 1964, z. 2, s.189-197.

111 Por. M. Wąsowicz, Kultura prawna w dorobku Profesora Juliusza Bardacha, [w:] Z dziejów kultury prawnej. Studia ofiarowane Profesorowi Juliuszowi Bardachowi $w$ dziewięćdziesięciolecie urodzin, red. M. Wąsowicz, Warszawa 2004, s. 11-17. Tu także bibliografia prac Bardacha (s. 19-68). 
w Wielkim Księstwie Litewskim ${ }^{112}$. Juliusz Bardach obszernie opisał, w jakich okolicznościach pojawiło się w Wielkim Księstwie prawo magdeburskie, a także jak Władysław Jagiełło zadekretował wprowadzenie w stołecznym Wilnie (magdeburskiego) ustroju Krakowa, do którego odwoływano się następnie w przywilejach wystawianych dla innych miast litewskich. Uczony przypominał, że na Litwie lokowano też miasta na prawie chełmińskim, które nota bene nie zawsze odróżniano od magdeburskiego.

\section{Podsumowanie}

Pojawienie się na terenie dawnej Polski i obowiązywanie aż do rozbiorów prawa sasko-magdeburskiego przyniosło historiografii multum problemów badawczych, niełatwych do opanowania. Polscy historycy prawa zapoczątkowali badania nad rolą, rozwojem i znaczeniem prawa magdeburskiego na ziemiach polskich już w XIX wieku. Znalazły one kontynuację w okresie dwudziestolecia międzywojennego i na szeroką skalę rozwijały się nadal po II wojnie światowej.

Historycy prawa w zasadzie nie angażowali się w toczącą się w pierwszych dziesięcioleciach PRL-u debatę mediewistów na temat roli Niemiec w powstaniu miast na ziemiach polskich. Wysiłek badawczy skupiali na analizie źródeł prawa magdeburskiego i jego odmian. Opisywali charakter i kształt dawnych spisów, kompilacji, a także kodyfikacji prawa magdeburskiego, chełmińskiego i średzkiego oraz ich znaczenie w praktyce sądowej. Przyglądali się genezie i dalszemu rozwojowi konstrukcji i instytucji prawnych pochodzenia niemieckiego.

Wysiłek badawczy polskich uczonych przyniósł wiele znakomitych, a niekiedy spektakularnych sukcesów - wydano liczne średniowieczne i nowożytne źródła pochodzenia magdeburskiego, także w przekładach polskich, zaopatrując je dodatkowo we wstępy

112 Miasta na prawie magdeburskim $w$ Wielkim Księstwie Litewskim od schyłku XIV do połowy XVII stulecia, Kwartalnik Historyczny 1980, t. 87, z. 1, s. 21-51. 
historyczne. Największe zasługi edytorskie stały się udziałem profesorów K. Koranyiego, L. Łysiaka, W. Maisla, Z. Rymaszewskiego i Z. Zdrójkowskiego. Ten ostatni kierował i przyczynił się do edycji tekstów prawa chełmińskiego, najbardziej rozpowszechnionej na gruncie polskim odmiany modelu magdeburskiego.

Ci historycy prawa, którzy podjęli szczegółowe studia nad źródłami, dostarczyli interesujących analiz na temat społecznej i gospodarczej roli prawa magdeburskiego oraz przejętych $z$ niego instytucji wymiaru sprawiedliwości jak też konstrukcji prawnych procesowych, karnistycznych i prywatnoprawnych. Najpoważniejszy wkład w studia nad analizą treści prawa magdeburskiego wnieśli profesorowie J. Matuszewski, W. Maisel, Z. Rymaszewski, a także romanista profesor J. Sondel, który szczególną uwagę poświęcił wpływom prawa rzymskiego na instytucje wywodzące się z Magdeburga. Do wymienionych uczonych - nestorów historii prawa - dołączyli w ostatnich latach przedstawiciele kolejnej generacji historycznoprawnej, dostarczając nowych studiów, przede wszystkim z zakresu prawa chełmińskiego.

\section{SUMMARY}

\section{The contribution of Polish legal historians to researches of Magdeburg law in XXth century (1945-2010)}

The author presents the studies of the legal historians on the role, development and significance of Magdeburg law that began in the Polish territories during the nineteenth century and flourished in the interwar period, and - on a larger scale - after World War II. Polish historians studies were focused on the analysis of sources of Magdeburg law and its local variations. The result was the publication of numerous sources of Magdeburg law, also in Polish translations and with historical comments. The largest contribution to the editing of sources brought professors: K. Koranyi, L. Łysiak, W. Maisel, Z. Rymaszewski and Z. Zdrojkowski. Numerous legal historians have taken detailed study of source texts, which resulted with the interesting elaborations on the social and economic role 
of the Magdeburg law and its legal structures: the organization of justice administration, due process, criminal law and private law. The most important descriptions of legal institutions, derived from the system of Magdeburg, was made by professors J. Matuszewski, W. Maisel, Z. Rymaszewski, J. Sondel. In recent years a younger generation of legal historians has taken a new study, especially in the law of Chelm (Chełmno), which was the most common variant of the Magdeburg law in Polish lands.

Key-words: law of Magdeburg, the history of law, Polish jurisprudence of twentieth century 